Nebojša Petković ${ }^{1}$

School of Economics in Nis, Serbia

Milan Rapajic ${ }^{2}$

Faculty of Law, University of Kragujevac, Serbia
ORIGINAL SCIENTIFIC ARTICLE

DOI: 10.5937/ekonomika2103039P

Received: Jun, 21. 2021.

Accepted: Jul, 11. 2021.

\title{
EMPLOYEES' SATISFACTION WITH COMMUNICATION IN THE ORGANIZATION
}

\begin{abstract}
Success of an organization is connected to employees' motivation and their satisfaction. Motivation growth in an organization is directly influenced by employees' communication at all levels. The subject of the survey is employees' satisfaction with communication in an organization. The aim of this work is to find out how 500 employees in Nis region estimate communication in an organization, the communication influence to the work motivation and work satisfaction in organization, how the employed managers value the superiors' communication to the employees, and which aspect of communication they are satisfied with, as well as how the employees and managers value the superiors' communication with the employees and which aspects of communication they are satisfied with. In the work the first to be analyzed were the relevant theoretical attitudes on the influence of employees' communication and communicational pleasure amongst them. The results of the realized empirical survey show that even though the employees at all levels in organization are definitely conscious of the importance of communication in organization, the managers have more positive attitude than the employees concerning the influence of certain communication on the work motivation and job satisfaction. There are remarkable differences in estimating satisfaction with certain aspects of communication, too, and the higher the position level of the observed in the organizational hierarchy is the more positive attitude on communication as a motivational factor in communication satisfaction is.
\end{abstract}

Key words: motivation, communication, organization, communication satisfaction.

JEL classification: M14, M12, D22.

\section{ЗАДОВОљСТВО ЗАПОСЛЕНИХ КОМУНИКАЦИЈОМ У ОРГАНИЗАЦИЈИ}

\section{Апстракт}

Успешност организащије повезана је са мотивисаношћу и задовољством запослених. На повећање мотивачије у организацији утиче комуникащија међу запосленима на свим нивоима. Предмет истраживања је задовољство

\footnotetext{
${ }^{1}$ nesapet@mail.ru, ORCID ID 0000-0002-8518-5344

${ }^{2}$ mrapajic@jura.kg.ac.rs, ORCID ID 0000-0002-1268-6826
} 
запослених комуникацијом у организацији. Циљ овог рада је да се утврди како 500 запослених у различитим организачијама нишавског округа оценује комуникачију у организацији, утицај одговарајуће комуникащије на повећање мотивачије за рад и задовољство послом у организацији, како запослени и менацери оцењују комуникацију запослених са надређенима и којим аспектима комуницирања су задовољни, али и како запослени и менаиери оценују комуникацију надређених са запосленима и којим аспектима комуницирања су задовољни? У раду су прво анализирани релевантни теоријски ставови о задовољству запослених као фактору њихове мотивачије, а потом и ствавови о утицају који комуникација има на мотиващију запослених и задовољство комуникаиијом међу запосленима у организачији. Резултати спроведеног емпиријског истраживања показују да, иако су запослени на свим нивоима у организацији свесни значаја комуникације у организаџији, менацери имају позитивнији став од запослених о утищају одговарајуће комуникације на мотивацију за рад и задовољство послом у организацији. Такође, да постоје значајне разлике у оцени задовољства неким аспектима комуницирања и да са повећањем нивоа позиције испитаника у организационој хијерархији позитивније постаје мишљење о комуникацији као мотивационом фактору и задовољству комуникацијом.

Кључне речи: мотивација, комуникащија, организащија, задовољство комуникацијом.

\section{Introduction}

Without adequate evaluation and motivation of employees, organizations cannot create and successfully adapt their offer to requirements of the environment. There is a direct positive relationship between the level of achievement of the organization's goals on one hand, and motivation and satisfaction of their employees, on the other hand. Satisfied and loyal employees create foundation for efficient work of the organization. Aware of the impact of communication on increasing employee motivation and the importance of building a communication system that leads to increased motivation and job satisfaction, managers strive to improve communication at all levels in the organization. The subject of this research is to assess employee satisfaction with communication in the organization, and the goal is to determine: Are the employees satisfied with communication in the organization? How much can appropriate communication increase motivation for work and job satisfaction in the organization? How employees and managers evaluate employees' communication with superiors and what aspects of communication are they satisfied with? How employees and managers evaluate superiors communication with employees and which aspects of communication are they satisfied with?

In order to prove that communication among employees at all levels increases employee motivation and job satisfaction in the organization, and that there is a difference between managers and employees in assessing satisfaction with some aspects of communication, the authors systematized and analyzed knowledge from relevant sources and conducted empirical research of employees satisfaction with communication 
in the organization. The authors analyze employee satisfaction as a determinant of their motivation, the impact of communication on development of employee motivation in the organization, and satisfaction with communication among employees in the organization, explain applied research methodology, and present results of empirical research and discuss the results.

\section{Employee satisfaction as a determinant of motivation}

In the era of accelerated economic processes, with frequent, sudden and unpredictable changes, organizations see employees as a key resource for achieving goals and a crucial factor of competitive advantage (Krstić, 2009). Employees are the basis of functioning of the organization, because only highly motivated and satisfied employees lead organization towards the set goals. The increase in success in performing employees tasks directly contributes to increase in the overall success of the organization. The efficiency of engaging human resources as a segment of total intellectual resources becomes a crucial factor in assessing economic strength of the organization (Veselinović, Krstić \& Veselinović, 2021).

Motivation and satisfaction of employees with work they perform become the key to success of the organization (Tanasijević, 2007). Job satisfaction is a pleasant or positive emotional state that results from a work experience (Locke \& Latham, 1990). It is the result of the employee's perception that his job enables him to achieve what is important to him and acquires a positive and mutual relation with life satisfaction (Judge \& Watanabe, 1993) and the impact of satisfaction on personal, social and working life (Sempane, Rieger \& Roodt, 2002).

Development of enthusiasm among employees who focus their efforts on achieving goals of the organization leads to better results (Vorina, Simonič \& Vlasova, 2017). Paying attention to employees can increase their productivity, increase level of job satisfaction and meeting needs through rewards for achievement, because it is in human nature to expect a reward for performing a certain activity (Vroom, 1964), while avoiding vaguely defined roles of team members, lack of trust between them, and inadequate reward system (Lazarević \& Lukić, 2018).

In order to increase business management efficiency in the organization, managers assign employees to those job positions where their characteristics can best be expressed (Petković \& Stanković, 2011), strive to "enrich" the work of employees through: creativity, innovation, greater autonomy in work, flexibility of working hours, teamwork, and the compensations that employees receive for successfully performed jobs and special efforts are harmonized with the recognized needs of employees that are different and require defining an appropriate reward system (Đorđević \& Đukić, 2005).

Employee satisfaction depends on their expectations and the extent to which they are achieved, and is measured by discrepancy between level of aspiration and achieved results. The quality of employee satisfaction assessment is conditioned by defining priorities of their needs. It is not possible to assess employee satisfaction without knowing the hierarchies of needs that are specific for them (Tanasijević, 2007). Job satisfaction is directly related to life satisfaction (Stepanov, Paspalj \& Butulija, 2016). Public sector research shows that four dimensions of organizational climate: reward orientation, 
responsibility, structure, and participation are significant factors of job satisfaction (Pangil, Yahya, Johari, Md Isa, \& Daud, 2011).

Doing jobs that employees do not like leads to dissatisfaction, frustration, unfulfillment, apathy, envy, and a whole range of other negative states and emotions. A successful and fulfilled life of an individual who has realized himself is directly related to his ability to discover potentials he was born with, and to use them. As people often lack the ability of self-awareness, it is up to managers to discover what talents, knowledge and abilities employees have, and which they can develop. Encouraging employees to develop their potentials raises level of employees' ability to do their jobs more efficiently. Self-realization and self-affirmation of employees increase their satisfaction, efficiency and effectiveness of the organization increases, a successful organization invests in development of employee potential through adequate communication, and employees further increase efficiency of their work.

Based on how much the organization manages to provide high quality employees, and then to organize and motivate them, the greater success will be in functioning of the organization. Due to the diversity of personality structure, specific knowledge and skills, different needs and preferences, employees are a specific factor of success of organizational functioning (Franceško \& Mirković, 2008). Organizing and motivating employees by harmonizing their different characters and expectations is a demanding task for the manager, especially if we keep in mind that employees primarily strive to achieve personal interests that may or may not be in line with organizational goals. In organizational culture development, the balance between business and private life can play a crucial role, employees focus on work activities, while at the same time creating a healthy counterbalance in the form of personal interests and family activities, and thus ultimately increasing productivity and other business performances of the organization (Mladenović \& Krstić, 2021).

\section{Influence of communication on employees motivation in the organization}

As the most important life skill for a person, represented in almost all human activities, communication is inseparable from work, and is a prerequisite for success in any business. To achieve high business performances of the organization, the quality of employees, their competencies, loyalty and commitment are important. It depends on building loyalty and commitment of employees to work they perform whether and to what extent employees will become factor of competitive advantage of the organization, and this can be crucially influenced by communication in the organization (Auer Antoncic \& Antoncic, 2011).

Communication is seen as a process of transmitting thoughts and ideas from one person to another (Francesco \& Gold, 2005, p. 70) in a way where it is expressed in a form the recipient can properly understand. It is the most common mean of exchanging information between employees at work, and between the organization and business environment. By exchanging information, between employees in the organization themselves, and between the organization and the business environment, relationships are established between people in which they exchange meaningful and clear messages of importance for whom they are intended. 
Communication is the basic element of socialization of each individual with a key role in creating relationships on private and business level (Bolfek, Milković \& Lukovac, 2017) and an important factor influencing employee satisfaction that results in higher productivity and business success. It is difficult to imagine business activities without communication, so naturally organizations are directed to communication, with successful communication among employees in the organization required for success (Kolev \& Tadić, 2017). Communication among employees in an organization is a strong factor of job satisfaction (Pettit, Goris \& Vaught, 1997). ${ }^{3}$

Communication, realized between all participants within the organization and through organization's contacts with environment, affects satisfaction of employees with work, and thus with success of the organization. Behavior of employees in the organization is directed in a way where they can meet their own needs, while meeting goals of the organization, because people become part of the organization guided by personal interests in meeting certain needs (Stepanov, Paspalj \& Butulija, 2016). Within the working hours that employees spend performing tasks, up to $80 \%$ are spent in communication: $9 \%$ in writing, $16 \%$ in reading, $45 \%$ in listening and 30\% in conversations with other employees (Kaser, 2013).

Problems in managing an organization are most often caused by poor communication - the recipient does not always have to understand what the sender of the message wanted to communicate, given that they have their own limitations and that there is much influence on message itself during transmission between them. Communication that is established at a satisfactory level between employees at all levels of the hierarchy and in both directions - both with superiors and with subordinates - is desirable. In order for the message to be adequately understood, it is assumed that the sender and the recipient have a common basis (Clark \& Brennan, 1991), such as education, experience, origin, value system, attitudes (Đorđević \& Ivanović Đukić, 2013).

\section{Satisfaction with communication in the organization}

Employees have different expectations from their communication relationships with immediate and senior executives (Pincus \& Ravfield, 1987). Managers' communication with employees, expressed through willingness to hear their problems and help solve them, will lead to a sense of security among employees, an increased sense of belonging to the community and self-affirmation. By sending incentive messages to employees, managers encourage their self-confidence and efficiency (Mihajlov \& Mihajlov, 2010). The greatest impact on employees feeling that the organization shows respect for their commitment and work results has the introduction of advanced technologies and modern means of work, with an increase in wages and a fairer distribution of income.

\footnotetext{
${ }^{3}$ Having used the data collected from 302 employees in two different production companies by using of moderated regression analysis, the authors have investigated the influence of communication between the employees in organization to relationship of performance results and work satisfaction, and concluded that horizontal communication coordinates the relation between salary satisfaction and performance results, while the information accuracy has shown the close connection between the work satisfaction and performance results, where communication dimensions of highest influence were information accuracy, interaction needs, communication pressure, confidence in the superior, the influence of the superior, and communication satisfaction.
} 
Communication increases job satisfaction and consequently develops work motivation (Milanović, \& Dragičević Radičević, 2019), there is a relation between satisfaction with communication in the organization and job satisfaction and work performances (Pincus, 1986) ${ }^{4}$, increase of communication efficiency between employees leads to increase in motivation of employees and increases their work capacity (So, et. al., 2018). There are no differences in the assessment of job satisfaction and communication among and between subordinate and superior groups (Steele \& Plenty, $2015)^{5}$. Socio-demographic characteristics of employees have a significant influence on certain dimensions of satisfaction with communication in the organization. The results of research on the importance of socio-demographic characteristics and personality dimensions of employees on communication satisfaction, in a sample of 119 employees was presented that, except for the gender structure of respondents, all other examined socio-demographic characteristics have an impact on certain dimensions of communication satisfaction (Nedeljković Knežević, Mijatov \& Nedeljković, 2019) ${ }^{6}$. Communication in the workplace can have a lasting effect on employee motivation: good communication raises quality of employee engagement, a sense of satisfaction with job, commitment to organization, and increase of trust in the workplace (Rajhans, 2012) ${ }^{7}$. The study concludes that there is a demand for effective communication as a result of employee relationship management, because communication in the organization plays a vital role in employee motivation and performance; modern organizations face a new reality - increased employee workload, longer working hours, greater emphasis on performance and risk, and communication among employees plays a crucial role in management efforts to redirect employees confused by changes, and informs and motivates those who adapt more easily.

Internal communication has a significant positive effect on employee satisfaction, and internal communication and employee satisfaction significantly influence internal integration, which subsequently affects external integration with business partners

\footnotetext{
${ }^{4}$ In a field study conducted on a sample of 327 nurses, Pincus (1986) investigated relationship between perceived satisfaction with communication in the organization and job satisfaction and work performances, and found significant positive relationships between: a) satisfaction with communication and job satisfaction, and b)satisfaction with communication and work performances.

5 The study examined communication competences, satisfaction with communication, and differences in job satisfaction within and between groups in the supervisor-subordinate relationship, as well as the relationship between three communication phenomena and satisfaction in a sample of 152 subordinates and 20 superiors in a public enterprise.

${ }^{6}$ Correlations were determined between certain dimensions of personality (extraversion, pleasantness, conscientiousness, openness to new experiences, neuroticism) and certain dimensions of employee satisfaction with communication (communication climate, communication with superiors, organizational integration, media quality, communication with employees, staff feedback, perspective of organizations).

7 The paper presents a study with findings on effects that communication in the organization has on employee motivation and performances, in an example of Vanaz Engineers Ltd., a large manufacturing company, known in India for various and quality products, specializing in the production of alternative fuels, auto components, valves, pressure/flow control devices, automatic LPG filling stations.
} 
(Jacobs, Yu \& Chavez, 2016) ${ }^{8}$. The process of internal communication directly affects building of relationships between managers and employees, effective communication improves climate in the work environment, increases employee awareness of activities and plans of the organization, through feedback managers receive employee suggestions, which fully uses accumulated experience of all its employees, improves the role of manager and gives a more positive attitude towards changes in the organization, increases opportunities to solve problems before they escalate into crises, creates and maintains employee commitment and concentrates efforts on ongoing tasks, while achieving company goals at the same time (Hola, 2012). Good internal communication depends on knowing and taking into account opinions of employees; if neglected, it can result in lack of motivation, resignation, and ultimately abandonment of the organization in favor of competition (Constantin \& Baiasa, 2015).

Satisfaction with communication among employees in the organization plays a significant role in increased employee engagement, internal communication and employee engagement are "powered" in a continuous virtual circle (Tkalac Verčič \& Pološki Vokić, 2017) ${ }^{9}$. Good communication between managers and other employees contributes to meeting basic needs of employees. They primarily enter into organization and "alliance" with other people in order to provide security, belonging and self-affirmation as basic needs, and communication itself is one of basic means to meet these needs. The communication climate among team members has a positive effect on creativity and internal motivation, further encouraged by external motivation (Zhu, Gardner \& Chen, 2016).

\section{Research methodology}

Research of employee satisfaction with communication in organizations of Nisava district was realized by applying a survey with 45 questions. The sample included 500 respondents: both sexes; different years of age and years of service; different education; social parents background; household type; employment status; current positions in the organization; number of employees in the organization; form of organizing organization; manufacturing, trade, banking, telecommunications, traffic, service, and administrative activities. 412 valid questionnaires were used for analysis.

Analysis of relevant theoretical sources in the field of management, psychology, sociology and marketing, and empirical research of employee satisfaction with communication in the organization, conducted using the survey method, are aimed at understanding relationship between employee position in the organization with communication satisfaction and aspects of communication, defined by the authors, which are satisfying for the managers and employees.

The method of generalization was used in determining basic concepts, starting points and appropriate assumptions; comparative method was used to record differences

\footnotetext{
${ }^{8}$ From the perspective of social capital theory, the study has investigated the effect of internal communication and employee satisfaction on supply chain integration, in an example of 214 Chinese manufacturers.

9 The results of study showed that employees are most satisfied with feedback, informal communication and communication during meetings.
} 
between individual categories, in order for these categories to be more completely determined in relation to each other; in order to record and consider key features of certain factors, methods of analysis and description were used; in order to contribute to adequate analysis of influence of employee behavior factors, methods of synthesis and logic were applied; in order to reach appropriate solutions from the initial hypotheses used in the research, the deductive method was used, and the inductive method was used to form and formulate appropriate conclusions. Quantitative data collected using the survey technique were processed in SPSS, and the use of statistical methods - descriptive statistics, $\chi 2$ test, correlation analysis via Spearman's correlation coefficient, Mann Whitney and Kruskal Wallis test, contributed to formulation of reliable conclusions.

Out of 412 respondents, $35(8.50 \%)$ are in top management, $57(13.83 \%)$ are the middle management level, and $61(14.81 \%)$ are first level of management, ie a total of $153(37.14 \%)$. ) managers. There are 259 (62.86\%) respondents in the position of employees: 128 (31.07\%) in the position of administrative jobs (a.j.) and 131 (31.79\%) employees in the position of technical jobs (t.p.).

In the research of employee satisfaction with communication in the organization, the authors asked following research questions:

1. Are employees satisfied with communication in the organization?

2. How much can appropriate communication increase motivation for work and job satisfaction in the organization?

3. How do employees and managers evaluate employees' communication with superiors and which aspects of communication are they satisfied with?

4. How do employees and managers evaluate communication of superiors with employees and which aspects of communication are they satisfied with?

\section{Research results and discussion}

1) In assessing satisfaction with communication among employees in the organization, $16.50 \%$ of respondents said that communication is very good, $17.48 \%$ that it is good, $40.29 \%$ took a neutral position, expressing opinion that communication among employees is satisfactory, $18,69 \%$ say it is weak, while $7.04 \%$ of respondents think that communication among employees in the organization is very poor. The above data indicate that the respondents do not think that communication among employees in the organization is $\operatorname{good}(1 / 3$ of respondents, or $33.98 \%$ ), while $40.29 \%$ consider it satisfactory. (Table 1 ).

Table 1. Assessment of respondents about communication among employees

\begin{tabular}{|l|c|c|}
\hline \multicolumn{1}{|c|}{ Evaluation of communication among employees } & Number of respondents & \% of respondents \\
\hline a) very good & 68 & 16,50 \\
\hline b) good & 72 & 17,48 \\
\hline c) satisfying & 166 & 40,29 \\
\hline d) weak & 77 & 18,69 \\
\hline e) very bad & 29 & 7,04 \\
\hline & 412 & 100,00 \\
\hline
\end{tabular}

Source: Author's research 
2) Of the total number of respondents, $35.68 \%$ believe that appropriate communication can greatly increase motivation for work and job satisfaction of employees in the organization, and $43.93 \%$ believe that appropriate communication can significantly increase motivation for work. The data above indicate that $3 / 4$ respondents $(79.61 \%)$ believe that appropriate communication can greatly and significantly increase the motivation for work and job satisfaction of employees in the organization. On the other hand, $17.48 \%$ of respondents believe that communication does not affect work motivation too much, and $2.91 \%$ of respondents believe that communication cannot affect work motivation at all (Table 2).

Table 2. Assessment of the impact of communication on increasing motivation for work and employee satisfaction with work in the organization

\begin{tabular}{|l|c|c|}
\hline $\begin{array}{c}\text { Assessment of communication impact on increasing } \\
\text { work motivation and employee job satisfaction }\end{array}$ & Number of respondents & \% of respondents \\
\hline a) greatly & 147 & 35,68 \\
\hline b) quite & 181 & 43,93 \\
\hline v) not too much & 72 & 17,48 \\
\hline g) not at all & 12 & 2,91 \\
\hline & 412 & 100,00 \\
\hline
\end{tabular}

Source: Author's research

The Kruskal Wallis test was used to examine differences in opinion on the influence of appropriate communication on work motivation between respondents at different positions in the organization (Table 3 ).

Table 3. Average values of attitudes about the impact of appropriate communication on the motivation for work of respondents at different positions

\begin{tabular}{|c|c|c|c|}
\hline Position in organization & Average value & Standard deviation & sig \\
\hline a) top management & 1,67 & 0,68 & \multirow{5}{*}{0,000} \\
\hline b) middle level management & 1,79 & 0,68 & \\
\hline v) first level management & 1,60 & 0,72 & \\
\hline g) employees at administrative positions & 1,81 & 0,85 & \\
\hline d) employees at technical positions & 2,15 & 0,79 & \\
\hline Total & 1,87 & 0,80 & \\
\hline
\end{tabular}

Source: Author's research

Based on obtained significance, it can be noticed that there is a significant difference $(\mathrm{sig}=0.000)$ between respondents at different positions in relation to opinion on influence of appropriate communication on work motivation. Average values show that managers have more positive attitude about the impact of appropriate communication on work motivation than employees, with first level managers having the most positive, and employees in technical jobs the most negative attitude.

The $\chi 2$ test was used to analyze influence of position in the organization on attitude about influence of appropriate communication on work motivation (Table 4). 
Table 4. $\chi^{2}$ test results of position influence in the organization on attitude about influence of appropriate communication on work motivation

\begin{tabular}{|l|c|c|c|c|c|c|c|}
\hline \multirow{2}{*}{$\begin{array}{c}\text { Communication increases } \\
\text { work motivation }\end{array}$} & \multicolumn{3}{|c|}{ Management } & \multicolumn{2}{|c|}{ Employees } & \multirow{2}{*}{$\chi^{2}$} & sig \\
\cline { 2 - 7 } & top & $\begin{array}{c}\text { middle } \\
\text { level }\end{array}$ & first level & adm.jobs & $\begin{array}{c}\text { techn. } \\
\text { jobs }\end{array}$ & \multirow{2}{*}{44,93} & \multirow{2}{*}{0,000} \\
\hline a) greatly & 16 & 21 & 32 & 52 & 28 & \\
\hline b) quite & 15 & 28 & 20 & 56 & 59 & \\
\hline v) not too much & 4 & 8 & 9 & 12 & 40 & \\
\hline g) not at all & 0 & 0 & 0 & 8 & 4 & & \\
\hline
\end{tabular}

Source: Author's research

Based on results of $\chi 2$ test, it can be seen that there is a connection between evaluation of appropriate communication impact on motivation to work with position of respondents in the organization. From the presented frequencies, it can be seen that all five categories of respondents according to positions in the organization generally positively observe impact of appropriate communication on work motivation, but it is noticeable that percentage of managers with positive opinions is significantly higher than percentage of employees with high grades.

To verify the fact that employees in all positions in organization generally positively perceive impact of appropriate communication on work motivation and that percentage of managers with a positive opinion is much higher than percentage of employees with high grades, Spearman's correlation coefficient was used (Table 5).

Table 5. Spearman's correlation coefficient of position in the organization and assessment of appropriate communication impact on work motivation

\begin{tabular}{|c|c|c|}
\hline $\begin{array}{c}\text { Correlation of position in organization and assessment of } \\
\text { appropriate communication impact on work motivation }\end{array}$ & \multicolumn{2}{|c|}{$\begin{array}{c}\text { Communication increases work } \\
\text { motivation }\end{array}$} \\
\hline Position in organization & Rs & 0,225 \\
\cline { 2 - 3 } & sig & 0,662 \\
\hline
\end{tabular}

Source: Author's research

The value of Spearman's correlation coefficient is statistically significant and positive. This confirms the fact that with increase of respondents position in organization, opinion about communication as a motivating factor becomes more positive.

3 ) In order to determine whether there are differences in employee satisfaction in communication with superiors in organization, data for employees and managers were separated.

Employees are most satisfied with availability of superiors to employees (3.76), using power that superior has to help employees solve problems at work (3.38) and existence of superiors' trust in employees (3.34), and least satisfied with stimulating employees in appropriate manner (2.95), frequency of meetings with employees (2.99), and creating opportunities for development and improving employees work skills (3.07) (Table 6). 
Table 6. Assessment of employees' degree of satisfaction with communication between employees and superiors

\begin{tabular}{|c|c|c|c|c|}
\hline $\begin{array}{l}\text { Aspects of communication between employees and } \\
\text { superiors }\end{array}$ & Min. & Max. & $\begin{array}{l}\text { Average } \\
\text { value }\end{array}$ & Stand. deviat. \\
\hline a) immediate superiors are available to employees & 1 & 5 & 3,76 & 1,16 \\
\hline $\begin{array}{l}\text { c) superior uses his power to help employees solve } \\
\text { problems at work }\end{array}$ & 1 & 5 & 3,38 & 1,25 \\
\hline e) superior has confidence in employees & 1 & 5 & 3,34 & 1,12 \\
\hline $\begin{array}{l}\text { b) superior knows problems of employees and helps } \\
\text { solving them }\end{array}$ & 1 & 5 & 3,34 & 1,14 \\
\hline 1) superior recognizes potential of employees & 1 & 5 & 3,33 & 1,30 \\
\hline j) is open and ready to hear remarks of employees & 1 & 5 & 3,27 & 1,34 \\
\hline $\begin{array}{l}\text { h) sends feedback to employees during } \\
\text { implementation of daily tasks }\end{array}$ & 1 & 5 & 3,25 & 1,14 \\
\hline $\mathrm{k})$ is open to new ideas and initiatives of employees & 1 & 5 & 3,20 & 1,22 \\
\hline $\begin{array}{l}\text { e) supports employees and is ready to pledge his } \\
\text { authority }\end{array}$ & 1 & 5 & 3,17 & 1,36 \\
\hline n) there is great trust of employees in superior & 1 & 5 & 3,10 & 1,27 \\
\hline $\begin{array}{l}\text { d) additionally motivates employees by getting } \\
\text { involved in decision making }\end{array}$ & 1 & 5 & 3,09 & 1,26 \\
\hline $\begin{array}{l}\text { i) creates opportunities for development and } \\
\text { improvement of business skills of employees }\end{array}$ & 1 & 5 & 3,07 & 1,16 \\
\hline m) superior often holds meetings with employees & 1 & 5 & 2,99 & 1,42 \\
\hline f) stimulates employees in appropriate manner & 1 & 5 & 2,95 & 1,31 \\
\hline
\end{tabular}

Source: Author's research

Managers are most satisfied with availability of immediate superiors to employees (3.96), using the power that superiors has to help employees solve problems at work (3.70) and sending feedback to employees during daily tasks (3.60), and existence of great trust of employees in superior is assessed the least strong (3.23), stimulation of employees in appropriate manner (3.25) and frequency of meetings with employees (3.28), which expressed the attitude that there is a lack of trust of employees in their superior, not to stimulate employees in an appropriate manner and not to hold meetings with employees often enough (Table 7). 
Table 7. Assessment of managers' degree of satisfaction with communication between employees and superiors

\begin{tabular}{|c|c|c|c|c|}
\hline $\begin{array}{l}\text { Aspects of communication between employees and } \\
\text { superiors }\end{array}$ & Min. & Max. & $\begin{array}{l}\text { Average } \\
\text { value }\end{array}$ & Stand. deviat. \\
\hline a) immediate superiors are available to employees & 1 & 5 & 3,96 & 1,01 \\
\hline $\begin{array}{l}\text { c) superior uses his power to help employees solve } \\
\text { problems at work }\end{array}$ & 1 & 5 & 3,70 & 1,06 \\
\hline $\begin{array}{l}\text { h) sends feedback to employees during implementation of } \\
\text { daily tasks }\end{array}$ & 1 & 5 & 3,60 & 1,02 \\
\hline d) the superior has confidence in employees & 2 & 5 & 3,57 & 0,96 \\
\hline $\begin{array}{l}\text { b) superior knows problems of employees and helps } \\
\text { solving them }\end{array}$ & 1 & 5 & 3,55 & 1,08 \\
\hline j) is open and ready to hear remarks of employees & 1 & 5 & 3,53 & 1,17 \\
\hline $\mathrm{k})$ is open to new ideas and initiatives of employees & 1 & 5 & 3,47 & 1,12 \\
\hline $\begin{array}{l}\text { i) creates opportunities for development and improvement } \\
\text { of business skills of employees }\end{array}$ & 1 & 5 & 3,44 & 1,10 \\
\hline 1) superior recognizes potential of employees & 1 & 5 & 3,43 & 1,11 \\
\hline e) supports employees and is ready to pledge his authority & 1 & 5 & 3,39 & 1,24 \\
\hline $\begin{array}{l}\text { g) additionally motivates employees by getting involved } \\
\text { in decision making }\end{array}$ & 1 & 5 & 3,29 & 1,11 \\
\hline m) superior often holds meetings with employees & 1 & 5 & 3,28 & 1,16 \\
\hline f) stimulates employees in appropriate manner & 1 & 5 & 3,25 & 1,20 \\
\hline n) there is great trust of employees in superior & 1 & 5 & 3,23 & 1,17 \\
\hline
\end{tabular}

Source: Author's research

To determine whether there is a statistically significant difference between employees and managers in assessing satisfaction degree of communication between employees and superiors in the organization, the Man Whitney test was performed (Table 8).

Table 8. Results of the Man Whitney test to compare differences between average values of employee satisfaction with communication with superiors, between employees and managers

\begin{tabular}{|l|c|c|c|c|c|}
\hline \multirow{2}{*}{$\begin{array}{c}\text { Aspects of communication between } \\
\text { employees and superiors }\end{array}$} & \multicolumn{2}{|c|}{ Employee } & \multicolumn{2}{c|}{ Managers } & \multirow{2}{*}{ sig } \\
\cline { 2 - 5 } & $\begin{array}{c}\text { Average } \\
\text { value }\end{array}$ & $\begin{array}{c}\text { Stand. } \\
\text { deviat. }\end{array}$ & $\begin{array}{c}\text { Average } \\
\text { value }\end{array}$ & $\begin{array}{c}\text { Stand. } \\
\text { deviat. }\end{array}$ & \\
\hline $\begin{array}{l}\text { a) immediate superiors are available to } \\
\text { employees }\end{array}$ & 3,76 & 1,16 & 3,96 & 1,01 & 0,138 \\
\hline $\begin{array}{l}\text { b) superior knows problems of employees } \\
\text { and helps solving them }\end{array}$ & 3,34 & 1,14 & 3,55 & 1,08 & 0,075 \\
\hline $\begin{array}{l}\text { c) superior uses his power to help employees } \\
\text { solve problems at work }\end{array}$ & 3,38 & 1,25 & 3,70 & 1,06 & 0,020 \\
\hline
\end{tabular}




\begin{tabular}{|c|c|c|c|c|c|}
\hline d) the superior has confidence in employees & 3,34 & 1,12 & 3,57 & 0,96 & 0,116 \\
\hline $\begin{array}{l}\text { e) supports employees and is ready to pledge } \\
\text { his authority }\end{array}$ & 3,17 & 1,36 & 3,39 & 1,24 & 0,176 \\
\hline $\begin{array}{l}\text { f) stimulates employees in appropriate } \\
\text { manner }\end{array}$ & 2,95 & 1,31 & 3,25 & 1,20 & 0,028 \\
\hline $\begin{array}{l}\text { g) additionally motivates employees by } \\
\text { getting involved in decision making }\end{array}$ & 3,09 & 1,26 & 3,29 & 1,11 & 0,170 \\
\hline $\begin{array}{l}\text { h) sends feedback to employees during } \\
\text { implementation of daily tasks }\end{array}$ & 3,25 & 1,14 & 3,60 & 1,02 & 0,002 \\
\hline $\begin{array}{l}\text { i) creates opportunities for development and } \\
\text { improvement of business skills of employees }\end{array}$ & 3,07 & 1,16 & 3,44 & 1,10 & 0,003 \\
\hline $\begin{array}{l}\text { j) is open and ready to hear remarks of } \\
\text { employees }\end{array}$ & 3,27 & 1,34 & 3,53 & 1,17 & 0,072 \\
\hline $\begin{array}{l}\text { k) is open to new ideas and initiatives of } \\
\text { employees }\end{array}$ & 3,20 & 1,22 & 3,47 & 1,12 & 0,037 \\
\hline 1) superior recognizes potential of employees & 3,33 & 1,30 & 3,43 & 1,11 & 0,544 \\
\hline $\begin{array}{l}\text { m) superior often holds meetings with } \\
\text { employees }\end{array}$ & 2,99 & 1,42 & 3,28 & 1,16 & 0,081 \\
\hline n) there is great trust of employees in superior & 3,10 & 1,27 & 3,23 & 1,17 & 0,322 \\
\hline
\end{tabular}

Source: Author's research

Based on obtained significance of differences between employees and managers, in assessing degree of satisfaction with communication between employees and superiors in the organization, it can be seen that statistically significant difference between managers and employees exists in assessing satisfaction with following aspects of employee communication with superiors: the superior uses his power to help employees solve problems at work ( $\operatorname{sig}=0.020)$; supports employees and is ready to pledge his authority $(\operatorname{sig}=0.028)$; sends feedback to employees during implementation of daily tasks ( $\mathrm{sig}=$ 0.002 ); creates opportunities for development and improvement of employees business skills $(\mathrm{sig}=0.003)$; is open to new ideas and initiatives of employees ( $\mathrm{sig}=0.037$ ). Managers are more satisfied with all these aspects of communication.

The Kruskal Wallis test was used to examine differences in average values of employee satisfaction with communication with superiors, between respondents in different positions in the organization (Table 9).

Table 9. Average values of satisfaction ratings of communication between employees and superiors for each position in organization

\begin{tabular}{|l|c|c|c|c|c|c|}
\hline \multirow{2}{*}{$\begin{array}{c}\text { Aspects of communication between } \\
\text { employees and superiors }\end{array}$} & \multicolumn{3}{|c|}{ Management } & \multicolumn{2}{c|}{ Employees } & \multirow{2}{*}{ sig } \\
\cline { 2 - 7 } & top & $\begin{array}{c}\text { middle } \\
\text { level }\end{array}$ & $\begin{array}{c}\text { first } \\
\text { level }\end{array}$ & admin. & tech. & \\
\hline $\begin{array}{l}\text { a) immediate superiors are available to } \\
\text { employees }\end{array}$ & 4,11 & 3,93 & 3,93 & 3,84 & 3,67 & 0,172 \\
\hline $\begin{array}{l}\text { b) superior knows problems of employees } \\
\text { and helps solving them }\end{array}$ & 4,00 & 3,50 & 3,40 & 3,41 & 3,24 & 0,004 \\
\hline
\end{tabular}




\begin{tabular}{|l|l|l|l|l|l|l|}
\hline $\begin{array}{l}\text { c) superior uses his power to help } \\
\text { employees solve problems at work }\end{array}$ & 4,22 & 3,71 & 3,40 & 3,44 & 3,30 & 0,000 \\
\hline d) the superior has confidence in employees & 4,00 & 3,50 & 3,47 & 3,25 & 3,39 & 0,015 \\
\hline $\begin{array}{l}\text { e) supports employees and is ready to } \\
\text { pledge his authority }\end{array}$ & 4,11 & 3,36 & 3,07 & 3,19 & 3,12 & 0,001 \\
\hline $\begin{array}{l}\text { f) stimulates employees in appropriate } \\
\text { manner }\end{array}$ & 4,00 & 3,29 & 2,87 & 3,00 & 2,85 & 0,000 \\
\hline $\begin{array}{l}\text { g) additionally motivates employees by } \\
\text { getting involved in decision making }\end{array}$ & 3,78 & 3,50 & 2,93 & 3,09 & 3,03 & 0,001 \\
\hline $\begin{array}{l}\text { h) sends feedback to employees during } \\
\text { implementation of daily tasks }\end{array}$ & 3,78 & 3,50 & 3,53 & 3,41 & 3,12 & 0,004 \\
\hline $\begin{array}{l}\text { i) creates opportunities for development } \\
\text { and improvement of business skills of } \\
\text { employees }\end{array}$ & 4,00 & 3,50 & 3,13 & 3,19 & 2,91 & 0,000 \\
\hline $\begin{array}{l}\text { j) is open and ready to hear remarks of } \\
\text { employees }\end{array}$ & 4,00 & 3,50 & 3,40 & 3,34 & 3,15 & 0,012 \\
\hline $\begin{array}{l}\text { k) is open to new ideas and initiatives of } \\
\text { employees }\end{array}$ & 3,78 & 3,71 & 3,13 & 3,38 & 3,00 & 0,000 \\
\hline $\begin{array}{l}\text { 1) superior recognizes potential of } \\
\text { employees }\end{array}$ & 4,11 & 3,29 & 3,20 & 3,47 & 3,18 & 0,001 \\
\hline $\begin{array}{l}\text { m) superior often holds meetings with } \\
\text { employees }\end{array}$ & 3,78 & 3,36 & 2,93 & 3,16 & 2,82 & 0,001 \\
\hline $\begin{array}{l}\text { n) there is great trust of employees in } \\
\text { superior }\end{array}$ & 3,89 & 3,21 & 2,87 & 3,19 & 3,00 & 0,001 \\
\hline
\end{tabular}

Source: Author's research

Based on the obtained significance of differences in average values of employee satisfaction with communication with superiors, between respondents in different positions in the organization, it can be said that a statistically significant difference between these categories of respondents exists in assessments of following aspects of communication: superior knows problems of employees and helps solving them $(\mathrm{sig}=0,004)$, superior uses the power he has to help employees solve problems at work ( $\operatorname{sig}=0,000)$, stimulates employees in an appropriate way $(\operatorname{sig}=0,000)$, sends feedback to employees during implementation of daily tasks $(\mathrm{sig}=0,004)$, creates opportunities for development and improvement of employees business skills ( $\mathrm{sig}=0.000$ ), is open and ready to hear remarks of employees ( $\operatorname{sig}=0.000)$, is open to new ideas and initiatives of employees ( $\operatorname{sig}=0.012)$, superior recognizes the potential of employees $(\mathrm{sig}=0.001)$, the supervisor often holds meetings with employees $(\mathrm{sig}=0.001)$; top managers are most satisfied with these aspects of communication, and employees in technical jobs are the least satisfied; the superior has confidence in employees ( $\mathrm{sig}=0.015)$; top managers are the most satisfied, and employees in administrative jobs are the least satisfied; supports employees and is ready to pledge his authority ( $\mathrm{sig}=0.001$ ), additionally motivates employees by getting involved in decisionmaking ( $\operatorname{sig}=0.001)$, there is great trust of employees in superiors ( $\operatorname{sig}=0.001)$; top managers are the most satisfied, and first-level managers are the least satisfied.

The relationship between degree of satisfaction with communication between employees and superiors and position of respondents in the organization was examined by analyzing Spearman's correlation coefficient (Table 10). 
Table 10. Spearman's correlation coefficient of position in the organization and degree of satisfaction with communication of employees with superiors

\begin{tabular}{|c|c|c|}
\hline \multirow{3}{*}{ Aspects of communication between employees and superiors } & \multicolumn{2}{|c|}{ Position in organization } \\
\hline & Rs & $-0,116$ \\
\hline & $\operatorname{sig}$ & 0,018 \\
\hline \multirow{2}{*}{ b) superior knows problems of employees and helps solving them } & Rs & $-0,156$ \\
\hline & sig & 0,002 \\
\hline \multirow{2}{*}{ c) superior uses his power to help employees solve problems at work } & Rs & $-0,175$ \\
\hline & $\operatorname{sig}$ & 0,000 \\
\hline \multirow{2}{*}{ d) the superior has confidence in employees } & Rs & $-0,109$ \\
\hline & sig & 0,027 \\
\hline \multirow{2}{*}{ e) supports employees and is ready to pledge his authority } & Rs & $-0,133$ \\
\hline & sig & 0,007 \\
\hline \multirow{2}{*}{ f) stimulates employees in appropriate manner } & Rs & $-0,180$ \\
\hline & sig & 0,000 \\
\hline \multirow{2}{*}{$\begin{array}{l}\text { g) additionally motivates employees by getting involved in decision } \\
\text { making }\end{array}$} & Rs & $-0,143$ \\
\hline & sig & 0,004 \\
\hline \multirow{2}{*}{ h) sends feedback to employees during implementation of daily tasks } & Rs & $-0,184$ \\
\hline & sig & 0,000 \\
\hline \multirow{2}{*}{$\begin{array}{l}\text { i) creates opportunities for development and improvement of business } \\
\text { skills of employees }\end{array}$} & Rs & $-0,235$ \\
\hline & sig & 0,000 \\
\hline \multirow{2}{*}{ j) is open and ready to hear remarks of employees } & Rs & $-0,155$ \\
\hline & $\operatorname{sig}$ & 0,002 \\
\hline \multirow{2}{*}{ k) is open to new ideas and initiatives of employees } & Rs & $-0,196$ \\
\hline & sig & 0,000 \\
\hline \multirow{2}{*}{ 1) superior recognizes potential of employees } & Rs & $-0,116$ \\
\hline & $\operatorname{sig}$ & 0,018 \\
\hline \multirow{2}{*}{ m) superior often holds meetings with employees } & Rs & $-0,162$ \\
\hline & sig & 0,001 \\
\hline \multirow{2}{*}{ n) there is great trust of employees in superior } & Rs & $-0,114$ \\
\hline & sig & 0,020 \\
\hline
\end{tabular}

Source: Author's research

Based on significance of Spearman 's correlation coefficient, there is a statistically significant correlation between employee satisfaction with communication with superiors and position of respondents in the organization in all aspects of communication. It can be noticed that all significant correlations are negative, which means that with increase of levels in organizational hierarchy, satisfaction with communication between employees and superiors also increases. 
4) In order to determine whether there is a difference in satisfaction with communication between superiors and employees in organization, data for employees and managers are separated.

Employees are most satisfied with responsible behavior of employees in relation to directives that are given to them (3.60) and responsibility of employees to send information towards superiors (3.51), and the worst rated was non-overburdening of superior with communication with employees (3.13) and sending necessary information from employees to their superior, even before they are asked (3.24) (Table 11).

Table 11. Assessment of employees'degree of satisfaction with communication between superiors and employees

\begin{tabular}{|c|c|c|c|c|}
\hline $\begin{array}{l}\text { Aspects of communication between employees and } \\
\text { superiors }\end{array}$ & Min. & Max. & $\begin{array}{l}\text { Average } \\
\text { value }\end{array}$ & $\begin{array}{l}\text { Stand. } \\
\text { deviation }\end{array}$ \\
\hline $\begin{array}{l}\text { d) employees act responsibly in relation to directives } \\
\text { addressed to them }\end{array}$ & 1 & 5 & 3,60 & 1,08 \\
\hline $\begin{array}{l}\text { b) employees have responsibility to send information } \\
\text { to superiors }\end{array}$ & 1 & 5 & 3,51 & 1,06 \\
\hline $\begin{array}{l}\text { e) employees accept evaluation of their work, } \\
\text { suggestions and criticism }\end{array}$ & 1 & 5 & 3,41 & 1,25 \\
\hline $\begin{array}{l}\text { c) employees send necessary information to their } \\
\text { superiors even before they are asked }\end{array}$ & 1 & 5 & 3,24 & 1,06 \\
\hline $\begin{array}{l}\text { a) the superior is not overburdened with } \\
\text { communication with employees }\end{array}$ & 1 & 5 & 3,13 & 1,17 \\
\hline
\end{tabular}

Source: Author's research

Managers are most satisfied with responsible behavior of employees in relation to directives addressed to them (3.60) and the responsibility of employees to send information to superiors (3.58), while they are least satisfied with non-overburdening superiors in communicating with employees (3.38) and sending necessary information from employees to superior even before they are asked (3.43) (Table 12).

Table 12. Assessment of managers'degree of satisfaction with communication between superiors and employees

\begin{tabular}{|l|c|c|c|c|}
\hline \multicolumn{1}{|c|}{ Aspects of communication between employees and } & Min. & Max. & $\begin{array}{c}\text { Average } \\
\text { value }\end{array}$ & $\begin{array}{c}\text { Stand. } \\
\text { deviation }\end{array}$ \\
\hline $\begin{array}{l}\text { d) employees act responsibly in relation to directives } \\
\text { addressed to them }\end{array}$ & 1 & 5 & 3,60 & 0,97 \\
\hline $\begin{array}{l}\text { b) employees have responsibility to send information to } \\
\text { superiors }\end{array}$ & 1 & 5 & 3,58 & 1,01 \\
\hline $\begin{array}{l}\text { e) employees accept evaluation of their work, } \\
\text { suggestions and criticism }\end{array}$ & 1 & 5 & 3,49 & 0,98 \\
\hline $\begin{array}{l}\text { c) employees send necessary information to their } \\
\text { superiors even before they are asked }\end{array}$ & 1 & 5 & 3,43 & 0,93 \\
\hline $\begin{array}{l}\text { a) the superior is not overburdened with communication } \\
\text { with employees }\end{array}$ & 1 & 5 & 3,38 & 0,97 \\
\hline
\end{tabular}

Source: Author's research 
To determine existence of statistically significant difference between employees and managers, in satisfaction degree assessment of communication between superiors and employees in the organization, the Man Whitney test was performed (Table 13).

Table 13. Results of the Man Whitney test to compare differences in average values of ratings of communication satisfaction of superiors with employees between employees and managers

\begin{tabular}{|c|c|c|c|c|c|}
\hline \multirow{2}{*}{$\begin{array}{l}\text { Aspects of communication between employees and } \\
\text { superiors }\end{array}$} & \multicolumn{2}{|c|}{ Employees } & \multicolumn{2}{|c|}{ Managers } & \multirow[b]{2}{*}{ sig } \\
\hline & $\begin{array}{l}\text { Aver. } \\
\text { val. }\end{array}$ & $\begin{array}{l}\text { Stand. } \\
\text { deviat. }\end{array}$ & $\begin{array}{l}\text { Aver. } \\
\text { val. }\end{array}$ & $\begin{array}{l}\text { Stand. } \\
\text { deviat. }\end{array}$ & \\
\hline $\begin{array}{l}\text { a) the superior is not overburdened with } \\
\text { communication with employees }\end{array}$ & 3,13 & 1,17 & 3,38 & 0,97 & 0,084 \\
\hline $\begin{array}{l}\text { b) employees have responsibility to send } \\
\text { information to superiors }\end{array}$ & 3,51 & 1,06 & 3,58 & 1,01 & 0,582 \\
\hline $\begin{array}{l}\text { c) employees send necessary information to their } \\
\text { superiors even before they are asked to do so }\end{array}$ & 3,24 & 1,06 & 3,43 & 0,93 & 0,039 \\
\hline $\begin{array}{l}\text { d) employees act responsibly in relation to } \\
\text { directives addressed to them }\end{array}$ & 3,60 & 1,08 & 3,60 & 0,97 & 0,743 \\
\hline $\begin{array}{l}\text { e) employees accept evaluation of their work, } \\
\text { suggestions and criticism }\end{array}$ & 3,41 & 1,25 & 3,49 & 0,98 & 0,694 \\
\hline
\end{tabular}

Source: Author's research

Based on obtained significance of difference between employees and managers in assessing degree of satisfaction with communication between superiors and employees in the organization, it can be concluded that statistically significant difference between managers and employees exists in assessment of satisfaction with communication aspect: "employees send necessary information to their superior even before hey are asked to do so" $($ sig $=0.039)$. Managers are more satisfied with this aspect of communication than employees.

Examining differences in average values of communication satisfaction ratings of superiors with employees between respondents at different positions in the organization was performed using the Kruskal Wallis test (Table 14).

Table 14. Average assessment values of satisfaction with communication between superiors and employees for each of the positions in organization

\begin{tabular}{|l|c|c|c|c|c|c|}
\hline \multirow{2}{*}{$\begin{array}{c}\text { Aspects of communication } \\
\text { between employees and superiors }\end{array}$} & \multicolumn{3}{|c|}{ Management } & \multicolumn{2}{c|}{ Employees } & sig \\
\cline { 2 - 7 } & top & $\begin{array}{c}\text { middle } \\
\text { level }\end{array}$ & first level & adm. & techn. & (3, \\
\hline $\begin{array}{l}\text { a) the superior is not } \\
\text { overburdened with } \\
\text { communication with employees }\end{array}$ & 3,33 & $3,43,00$ & 0,083 \\
\hline $\begin{array}{l}\text { b) employees have responsibility } \\
\text { to send information to superiors }\end{array}$ & 3,78 & 3,50 & 3,53 & 3,66 & 3,36 & 0,141 \\
\hline $\begin{array}{l}\text { c) employees send necessary } \\
\text { information to their superiors } \\
\text { even before they are asked to } \\
\text { do so }\end{array}$ & 3,67 & 3,57 & 3,07 & 3,50 & 3,03 & 0,000 \\
\hline
\end{tabular}




\begin{tabular}{|l|c|c|c|c|c|c|}
\hline $\begin{array}{l}\text { d) employees act responsibly in } \\
\text { relation to directives addressed } \\
\text { to them }\end{array}$ & 3,89 & 3,64 & 3,27 & 3,88 & 3,39 & 0,000 \\
\hline $\begin{array}{l}\text { e) employees accept evaluation } \\
\text { of their work, suggestions and } \\
\text { criticism }\end{array}$ & 3,78 & 3,57 & 3,13 & 3,44 & 3,42 & 0,070 \\
\hline
\end{tabular}

Source: Author's research

Based on obtained significance differences in the average values of satisfaction assessments of communication between superiors and employees, between respondents in different positions in the organization can be seen that a statistically significant difference between these categories of respondents exist in satisfaction assessments of the following aspects of communication between superiors and employees: employees send necessary information to their superiors even before being asked ( $\operatorname{sig}=0.000$ ); top managers are most satisfied, and employees in technical jobs are least satisfied; employees behave responsibly in relation to directives addressed to them $(\mathrm{sig}=0.000)$; top managers are most satisfied, and first-level managers are least satisfied.

Connection between degree of satisfaction with communication between superiors and employees and position of respondents in organization was examined also by analyzing Spearman's correlation coefficient (Table 15).

\section{Table 15. Spearman's correlation coefficient of position in organization and degree of} satisfaction with communication between superiors and employees

\begin{tabular}{|l|c|c|}
\hline \multicolumn{1}{|c|}{ Aspects of communication between employees and superiors } & \multicolumn{2}{|c|}{ Position in organization } \\
\hline \multirow{2}{*}{ a) the superior is not overburdened with communication with employees } & Rs & $-0,118$ \\
\cline { 2 - 3 } & sig & 0,016 \\
\hline \multirow{2}{*}{ b) employees have responsibility to send information to superiors } & Rs & $-0,077$ \\
\cline { 2 - 3 } c) employees send necessary information to their superiors even before they & sig & 0,118 \\
\cline { 2 - 3 } are asked to do so & Rs & $-0,187$ \\
\hline \multirow{2}{*}{ d) employees act responsibly in relation to directives addressed to them } & sig & 0,000 \\
\cline { 2 - 3 } & Rs & $-0,085$ \\
\hline e) employees accept evaluation of their work, suggestions and criticism & Rs & $-0,035$ \\
\cline { 2 - 3 } & sig & 0,481 \\
\hline
\end{tabular}

Source: Author's research

Based on Spearman's correlation coefficient significance, there is a statistically significant correlation between superior satisfaction with communication with employees and position in the organization in terms of communication: "superior is not overloaded with communication with employees" ( $\mathrm{Rs}=-0.118$, sig $=0.016)$ and "employees send necessary information to their superiors even before they are asked to do so" (Rs $=-0.187$, 
sig $=0.000$ ). It can be noticed that significant correlations are negative, which means that with increase of levels in organizational hierarchy, satisfaction with communication between superiors and employees also increases.

\section{Conclusion}

Summarizing results of empirical research, it can be concluded:

1) Employees and managers evaluate communication among employees in the organization as good and satisfactory.

2) Appropriate communication can increase greatly and to quite extent motivation for work and job satisfaction of employees in organization, managers have more positive attitude about impact of appropriate communication on work motivation than employees, and with increasing position of respondents in organization, the more positive opinion on communication as a motivational factor becomes.

3) The results of the survey on employee communication satisfaction with superiors show following:

a. Employees are most satisfied with availability of superiors to employees, using power that superiors have to help employees solve problems at work, and existence of superiors' trust in employees, and least satisfied with stimulating employees appropriately, frequency of meetings with employees, and creating opportunities for development and improvement employee work skills.

b. Managers are most satisfied with availability of immediate superiors to employees, using power that superior has to help employees solve problems at work and sending feedback to employees in implementation of daily tasks, and least rated is existence of great trust of employees in superior, stimulating employees appropriately and frequent holding meetings with employees, thus expressing the view that employees lack trust in their superior, that employees are not stimulated in appropriate manner, and that meetings with employees are not held often enough.

c. Significance of differences between employees and managers in assessing communication satisfaction between employees and superiors in the organization shows that managers are more satisfied than employees with following aspects of employee communication with superiors: superior uses his power to help employees solve problems at work, supports employees and is ready to pledge his authority, sends feedback to employees during implementation of daily tasks, creates opportunities for development and improvement of business skills of employees and is open to new ideas and initiatives of employees.

d. Astatistically significant difference between respondents at different positions in organization exists in assessment of following aspects of communication:

- Top managers are most satisfied, and employees in technical jobs are least satisfied with aspects of communication: superior knows problems of employees and helps solve them, superior uses power he has to help 
employees solve problems at work, stimulates employees appropriately, sends feedback to employees during implementation of daily tasks, creates opportunities for development and improvement of employees work skills, is open and ready to hear comments from employees, is open to new ideas and initiatives of employees, superior recognizes employee potential, superior often holds meetings with employees.

- Top managers are most satisfied, and employees in administrative jobs are least satisfied with communication aspect: superior has confidence in employees.

- Top managers are most satisfied, and first-level managers are least satisfied with communication aspect: supports employees and is ready to pledge his authority, additionally motivates employees by involving them in decision-making, there is great trust of employees in superiors.

e. As the level in the organizational hierarchy increases, so does the satisfaction of employees communicating with superiors.

4) The results of survey on satisfaction with communication between superiors and employees show following:

a. Employees are most satisfied with responsible behavior of employees in relation to directives given to them and responsibility of employees to send information to superiors, and they have rated with lowest grades the nonoverburdening superior with communication with employees and sending necessary information to employees even before being asked.

b. Managers are most satisfied with responsible behavior of employees in relation to directives given to them and responsibility of employees to send information to superiors, while they are least satisfied with nonoverburdening superiors with communication with employees and sending necessary information to employees even before being asked.

c. The significance of difference between managers and employees in assessing degree of satisfaction with communication between superiors and employees in organization shows that managers are more satisfied than employees with communication aspect: employees send necessary information to superiors even before they are asked.

d. There is statistically significant difference between respondents in different positions in organization in assessing satisfaction with following aspects of communication between superiors and employees:

- Top managers are the most satisfied, and employees in technical jobs are the least satisfied with communication aspect: employees send necessary information to their superiors even before they are asked.

- $\quad$ Top managers are the most satisfied, and first-level managers are the least satisfied with communication aspect: employees behave responsibly in relation to directives given to them.

e. As the level in organizational hierarchy increases, so does the satisfaction with communication between superiors and employees.

Although the research, according to statistical population, is extensive, it also has limitations that are reflected in coverage of local geographical area in which the 
research was conducted, and the use of data from one period - period when research was conducted. These limitations can be removed by future researching with a larger coverage of statistical population in a wider geographical area and by repeating the research.

\section{References}

Auer Antoncic, J., \& Antoncic, B. (2011). Employee Loyalty And Its Impact On Firm Growth. International Journal of Management \& Information Systems (IJMIS), 15(1), 81-88.

Bolfek, B., Milković, V., \& Lukovac, M. (2017). Utjecaj interne komunikacije na zadovoljstvo zaposlenika radnim mjestom. Oeconomica Jadertina, 7(1), 16-27.

Clark, H. H., \& Brennan, S. E. (1991). Grounding in communication: Perspectives on socially shared communication. Washington: American Psychological Association. (citirano u Thomas, C. D. (2008). Cross - Cultural Management Essential Concepts. Thousand Oaks: SAGE Publications, Inc.).

Constantin, E. C., \& Baiasa, C. C. (2015). Employee Voice - Key Factor in Internal Communication. Procedia - Social and Behavioral Sciences, 191, 975-978.

Đorđević, A., \& Đukić, M. (2005). Sistem nagrađivanja zaposlenih u hotelijerstvu u funkciji motivacije. Turizam, 9, 146-148.

Đorđević, B., \& Ivanović Đukić, M. (2013). Izazovi međunarodnog poslovnog komuniciranja i implikacije za menadžment ljudskih resursa. Ekonomske teme, 51(2), 273-292.

Francesco, M. A., \& Gold, A. G. (2005). International Organizational Behavior. New Jersey: Perason Pretince Hall.

Franceško, M., \& Mirković, B. (2008). Organizaciono ponašanje: Moć poznavanja organizacionog ponašanja. Univerzitet za poslovni inženjering i menadžment, Banja Luka.

Hola, J. (2012). Internal communication in the small and medium sized enterprises. EaM: Ekonomie a Management, 15(3), 32-45.

Jacobs, M. A., Yu, W., \& Chavez, R. (2016). The effect of internal communication and employee satisfaction on supply chain integration. International Journal of Production Economics, 171(1), 60-70.

Judge, T. A., \& Watanabe, S. (1993). Another look at the job satisfaction - life satisfaction relationship. Journal of Applied Psychology, 78, 939-948.

Kaser, K. (2013). Advertising and Sales Promotion. South-Western, Mason.

Kolev, D., \& Tadić, D. (2017). Korporativna interna komunikacija kao faktor efikasnog poslovanja merena „think-feel-do“ metodom (Case study). The Journal „Economy and Market Communication Review - Časopis za ekonomiju i tržišne komunikacije ", 7(2), 213-234.

Krstić, B. (2009). Upravljanje intelektualnim performansama preduzeća. Ekonomske teme, 47(2), 59-72. 
Lazarević, S., \& Lukić, J. (2018). Team Learning Processes and Activities in Organization: A Case Study. Economic Themes, 56(3), 301-319.

Locke, E. A., \& Latham, G. P. (1990). Theory of goal setting and task performance. Englewood Cliffs, New York: Prentice-Hall.

Mihajlov, S., \& Mihajlov, N. (2010). Inspirativna komunikacija lidera i njen uticaj na motivaciju zaposlenih. BizInfo, 2, 59-67.

Milanović, V., \& Dragičević Radičević, T. (2019). Odnosi između zadovoljstva komunikacijom, zadovoljstva poslom i postignuća na poslu - pregled važnijih empirijskih istraživanja od 1970. godine. CM: Communication and Media, XIV(46), 89-120.

Mladenović, M. \& Krstić, B. (2021). Barriers and measurement of work/life balance of managers and other employees, Economics of Sustainable Development, 5(1), 23-31.

Nedeljković Knežević, M., Mijatov, M., \& Nedeljković, S. (2019). The importance of sociodemographic characteristics and personality dimensions for communication satisfaction. Economic Horizons, 21(3), 239-262.

Pangil, F., Yahya, K. K., Johari, J., Md Isa, M. F., \& Daud, Z. (2011). The relationship between organizational climate and job satisfaction: The case of a government agency in Malaysia. International Journal of Humanities and Social Science, 1(12), 152-160.

Pettit, J. D., Goris, J. R., \& Vaught, B. C. (1997). An Examination of Organizational Communication as a Moderator of the Relationship Between Job Performance and Job Satisfaction. The Journal of Business Communication (1973), 34(1), 81-98.

Petković, T., \& Stanković R. (2011). Strategijski menadžment. Visoka poslovna škola strukovnih studija, Čačak.

Pincus, J. D. (1986). Communication Satisfaction, Job Satisfaction and Job Performance. Human Communication Research, 12(3), 395-419.

Pincus, J. D., \& Ravfield, R. E. (1987). The relationship between top management communication performance and job satisfaction. Communicare: Journal for Communication Sciences in Southern Africa, 6(2), 14-26.

Rajhans, K. (2012). Effective Organizational Communication: a Key to Employee Motivation and Performance. Interscience Management Review (IMR), 2(2).

Sempane, M. E., Rieger, H. S., \& Roodt, G. (2002). Job satisfaction in relation to organisational culture. South African Journal of Industrial Psychology, 28(2), 23-30.

So, I. G., Noerlina, Djunggara, A. A., Fahrobi, R., Simamora, B. H., \& Ruangkanjanases, A. (2018). Effect of Organisational Communication and Culture on Employee Motivation and Its Impact on Employee Performance. Pertanika J. Soc. Sci. \& Hum, 26(2), 1133-1142.

Steele, G. A., \& Plenty, D. (2015). Supervisor-subordinate communication competence and job and communication satisfaction. International Journal of Business Communication, 52(3), 294-318. 
Stepanov, S., Paspalj, D., \& Butulija, M. (2016). Motivacija zaposlenih kao ključni pokazatelj zadovoljstva poslom. Ekonomija, teorija i praksa, IX(2), 53-67.

Tanasijević, Z. (2007). Zadovoljstvo zaposlenih - izvor ili rezultat motivacije zaposlenih, Festival kvaliteta 2007 - 34 nacionalna konferencija o kvalitetu. Kragujevac, Asocijacija za kvalitet i standardizaciju Srbije.

Tkalac Verčič, A., \& Pološki Vokić, N. (2017). Engaging employees through internal communication. Public Relations Review, 43(5), 885-893.

Vorina, A., Simonič, M., \& Vlasova, M. (2017). An Analysis of the Relationship Between Job Satisfaction and Employee Engagement. Economic Themes, 55(2), 243-262.

Veselinović, N., Krstić, B., \& Veselinović, N. (2021). Measuring the efficiency of human capital. Economics of Sustainable Development, 5(2), 1-16.

Vroom, V. H. (1964). Work and Motivation. New York: Wiley.

Zhu, Y. Q., Gardner, D. G., \& Chen, H. G. (2016). Relationships Between Work Team Climate, Individual Motivation, and Creativity. Journal of Management, 44(5). 
